\title{
TRANSITIVITY ANALYSIS OF TENTH GRADE STUDENTS' DESCRIPTIVE TEXT
}

\author{
Nur Rohmat, Nurhaeni, Anita Anggraeni \\ IKIP Siliwangi, Bandung \\ IKIP Siliwangi, Bandung \\ IKIP Siliwangi, Bandung
}

nrohmat1994@gmail.com, enys0633@gmail.com, anitaenglish26@gmail.com

\begin{abstract}
The objective of the research is to investigate the use of transitivity process in students' descriptive text and to find out the most dominant process of transitivity used. The data analyzed were 46 clauses taken from descriptive text written by six students of tenth grade of senior high school. In this research, the writers used descriptive qualitative method. The result of the research showed that there were 4 types of processes that occurred in the data, they were: material process $(8,70 \%)$, mental process $(17,39 \%)$, relational process $(45,65 \%)$, and existential process $(28,26 \%)$. While, behavioral and verbal process were not found. The most dominant process found was relational process. It implies that students were aware how descriptive text should be written, since one of language features in descriptive text is using clauses with relational process.
\end{abstract}

Keywords: SFL, Transitivity, Descriptive Text

\section{INTRODUCTION}

Writing is one language skill which is important to master, beside listening, speaking and reading. Nunan (2003) argues that writing is a process which involves physical and mental act to make ideas, express them, and organize them into sentences and paragraphs which will be clear for reader. The purpose of writing is to express writers' ideas, whether it is for themselves or their audiences. By having good writing skill, the writers will be able to share ideas to wide range of audience without through face to face or telephone conversation. Most of people use writing to communicate each other. Writing can help us to express our idea in written form and writing is used for communication. In Indonesia, based on 2013 curriculum, descriptive text is one of writing genres that should be learned by students of tenth grade of senior high school.

The word 'descriptive' is derived from word describe, which means drawing, illustrating, or picturing particular object in order to visualize the object described (Dirgeyasa, 2016). According to Gerot \& Wignell (1995), descriptive text is type of text in which its social function is to describe a particular person, place, or thing. In addition, Oshima and Hogue (1997 cited in Anggun, 2016) stated that descriptive writing appeals to the senses, so it tells how something looks, feels, smells, tastes, and/ or sounds.

Learning descriptive genre is essential for students, in order they can describe vivid and proper information (Emilia \& Christie, 2013 cited in Anggun, 2016). Since learning descriptive genre is important, students should be able to write descriptive text in correct way. Students' descriptive text need to fulfill the structure and language features of descriptive text. 
Gerot \& Wignell (1995: 208) formulates some language features of descriptive text, one of them is using clause with attributive and identifying processes.

Attributive and identifying process are two terms in Systemic Functional Linguistic. Systemic Functional Linguistic (SFL), or also known as functional grammar is language approach which mainly developed by M.A.K Halliday in 1960's in UK, and in Australia later (O 'Donnell, 2011). Systemic Functional Linguistic is an approach in discourse analysis which focuses on social, semiotic, and functional aspect of language (Nguyen, 2012 cited in Zahoor \& Janjua, 2016). SFL has been used in world-word for some purposes, such as discourse analysis (Almurashi, 2016).

Gerot \& Wignell (1995: 4-7) stated that functional grammar in SFL is different with traditional grammar and formal grammar. Traditional grammar and formal grammar are concerned on structure of sentences. While, functional grammar focuses on texts and their contexts. Moreover, functional grammar is related to how structures create meaning.

In SFL, language meaning is classified into three types of metafunctions, which are: ideational, personal, and textual (Gerot \& Wignell, 1995: 12). Ideational metafunction express about phenomena, things, goings on, and their circumstances. Interpersonal metafunction express a speaker's attitudes and judgements. Textual metafunction express how language and its environment being related. From those three metafunctions, the writers choose ideational metafunction as focus of the research.

In ideational metafunction, there is transitivity system as its sub-network. Transitivity system refers to the predicate types of a language and the participant roles with which they combine (Teich, 1999 cited in Senjawati, 2016). Halliday \& Matthiessen (2004: 181) defined transitivity as clause system which involves process, participants and circumstances. Process is the central of transitivity which typically realized by verb. Process refers to a semantic verb (doing, happening, feeling, sensing, saying, behaving, and existing) and anything that it expresses like event, relation, physical, mental or emotional state (Halliday, 1976 cited in Haratyan, 2011). Participant is element which involved in process directly. It refers to an entity or thing. Participant is typically realized by noun. Circumstances are additional to the process. They realize meaning about time, place, manner, cause, accompaniment, and matter. Circumstances are typically realized by adverbial group or prepositional group. Furthermore, Halliday \& Matthiessen (2004) categorized transitivity process into six types, which are material process, mental process, relational process, behavioral process, existential process, and verbal process.

The first process is material process. It represents the process of doing and happening. There are two main participants involved in material process, they are actor and goal. Actor is something doing the process. Goal is something to whom the process is directed. Beside these two participants, there are four other participants; they are scope, recipient, client, and attribute.

The second is mental process which represents the process of feeling, thinking, and perceiving. Gerot \& Wignell (1995: 58) stated that mental process is divided into three types, which are affective, cognitive, and perceptive. There are two participants involved in mental process, they are: senser which refers to something who can feel, think, or see; and phenomenon - something which is sensed 
The third is relational process. It serves to characterize and to identify. In other word, Gerot \& Wignell (1995: 67) define relational process as a process in which states of being and having are involved. Relational process is classified into two parts, they are identifying process and attributive process. Identifying process establish an identity, while attributive is process which assign a quality. Identifying process has two participants, they are token and value. Attributive process also takes two participants, which are carrier and attribute.

The fourth is behavioral process, in which it is proses that represents manifestations of inner working, acting out of consciousness process, and physiological states (Halliday \& Matthiessen, 2004 : 171). Behavioral process lie between material and mental process (Zahoor \& Janjua, 2016). Behavioral process involves one participant, it is behaver.

The fifth process is existential process. This process represents the existence of something. It is borderline between relational and mental process. Usually, this process use 'there' as its subject. In this case, the word 'there' has no representational function. This process also involves only one participant, it is existent.

The sixth process is verbal process which borderline of mental and relational process. Verbal process represents the act of saying or meaning. The participants of this process are: sayer (participant who says), receiver (participant which to whom the verbalization is addressed), target (the one acted upon verbally), and verbiage (a name for verbalization itself) (Gerot \& Wignell, 1995).

Table 1. Example of Transitivity Processes adapted from Halliday \& Matthiessen (2004)

\begin{tabular}{cc} 
Process & $\begin{array}{c}\text { Example (participants underlined, process in bold, circumstances } \\
\text { in italics) }\end{array}$ \\
\hline Material & During the European scramble for Africa, Nigeria fell to the British. \\
\hline Mental & $\underline{\text { The Ibos did not approve of kings. }}$ \\
\hline Relational & $\underline{\text { Every fourth African is a Nigerian. }}$ \\
\hline Behavioral & $\underline{\text { People are laughing. }}$ \\
\hline Existential & today there's Christianity in the south \\
\hline Verbal & $\underline{\text { We say that every fourth African is a Nigerian }}$
\end{tabular}

Transitivity has been widely used by previous researchers as analytical tool for analyzing discourse. The first is research conducted by Anggun (2016). This research used transitivity analysis to investigate to what extent the descriptive texts in English textbook meet its criteria in terms of purposes, schematic structures and linguistic features. The second research is conducted by Zahoor \& Janjua (2016). The main focus of this research was to analyze transitivity patterns in song "I am Malala". The third is research conducted by (Senjawati, 2016) which used transitivity in investigating students recount text.

In this research, the writers were also interested to use transitivity system to analyze descriptive text written by students of tenth grade of senior high school. The objective of the research is to investigate the use of transitivity process in students' descriptive text and to find out the most dominant process of transitivity used. By knowing the most dominant process used, the writers would be able to know students' ability in writing descriptive text from transitivity perspective, since one of lexicogrammaticals used in descriptive text is using 
attributive and identifying process. The title of this research is Transitivity Analysis of Tenth Grade Students' Descriptive Text.

\section{METHOD}

Descriptive qualitative was the method used in conducting this study. The writers conducted this research in one of senior high school in Bandung Barat, Jawa Barat, Indonesia. This research involved six students of tenth grade of senior high school. Tenth-grade was chosen because curriculum of tenth grade contains descriptive text, in which it was the focus of the research. The data used was descriptive text written by six students. Before students write descriptive text, the writers gave clear explanation about description to the students. It consists of definition, purpose, structure, language features, and examples of descriptive text. Then, students were asked to write descriptive text about tourism place.

In analyzing the data, the writers divide each sentence in students' descriptive text into clauses. After that, the writers identified and classified the clauses based on six types of processes in transitivity. Then, the occurrence of each process was counted in order to find out the most dominant process used in students' descriptive text. Then, implication of the most dominant process found was described.

\section{RESULTS AND DISCUSSION}

\section{Results}

The writers presented data taken from descriptive texts written by six students of tenth grade of senior high school. Each clause of the texts was analyzed into process types of transitivity system. They are material process, behavioral process, mental process, relational process, verbal process and existential process. In this case, there are 46 clauses found and analyzed. The distribution of process types of each student's text can be seen in the table below.

Table 2. Distribution of Processes in Each Student's Descriptive Text

\begin{tabular}{ccccccc}
\hline \multirow{2}{*}{ Participants } & \multicolumn{7}{c}{ Process } \\
\cline { 2 - 7 } & Material & Mental & Relational & Behavioral & Verbal & Existential \\
\hline Student 1 & 1 & 1 & 3 & - & - & 1 \\
\hline Student 2 & - & - & 4 & - & - & 7 \\
\hline Student 3 & - & 2 & 2 & - & - & 2 \\
\hline Student 4 & 1 & 1 & 5 & - & - & - \\
\hline Student 5 & 3 & 1 & 3 & - & - & - \\
\hline Student 6 & - & 2 & 4 & - & - & 3 \\
\hline Total & 4 & 8 & 21 & - & - & 13 \\
\hline
\end{tabular}

From the table above, it can be seen that material process occurred 4 times, mental process occurred 8 times, relational process occurred 21 times, and existential process occurred 13 times. While, behavioral process and verbal process did not occur. 
Table 3. Appearances of Processes

\begin{tabular}{ccc}
\hline Process & Frequency of Appearances & Percentages \\
\hline Material & 4 & $8,70 \%$ \\
\hline Mental & 8 & $17,39 \%$ \\
\hline Relational & 21 & $45,65 \%$ \\
\hline Behavioral & - & - \\
\hline Verbal & - & - \\
\hline Existential & 13 & $28,26 \%$ \\
\hline Total & 46 & $100 \%$ \\
\hline
\end{tabular}

Table 3 shows that relational process is the most process found in the data, it is about $45,65 \%$ or 21 clauses. Relational process refers to process of being and having. The second is existential process. It appears 13 times $(28,26 \%)$ which refers to process of existence. The third is mental process. It refers to process of sensing. It is about $17,39 \%$ ( 8 clauses). The last is material process which refers to process of doing. It appears 4 times $(8,70 \%)$.

\section{Discussion}

This part discusses the general interpretation of process types found in the data. Based on the data calculation above, there are four process types found, which are material process, mental process, relational process, and existential process. The explanation below is sorted by the frequency of occurrence of process types.

The first is relational process. The writer found 21 relational processes from all of the data analyzed. Relational process is classified into two forms, which are attributive process and identifying process. However, the writer found attributive process only of the whole texts. Attributive process occurred 21 times, which can be found from the text written by student 1 (3 clauses), student 2 (4 clauses) and student 3 ( 2 clauses), student 4 (5 clauses), student 5 (3 clauses), student 6 (4 clauses). Here are some clauses with attributive process found:

\begin{tabular}{|c|c|c|}
\hline Horse tours & a $\mathrm{p}$ & place of family tour \\
\hline Carrier & Attributive & Attribute \\
\hline It & looks & so amazing \\
\hline Carrier & Attributive & Attribute \\
\hline The place & is & cool and crowded \\
\hline Carrier & Attributive & Attribute \\
\hline
\end{tabular}

Students used clauses with relational process for explaining and identifying what students described. For example, from the clause 'Horse tours is a place of family tours', the student tried to give explanation what 'horse tours' is. Those clauses are attributive processes 
because the second participant of each clause (attributive) explains the first participant (carrier).

The second process found is existential. Halliday \& Matthiessen (2004: 256) argued that existential process can be defined as process of existing of something. There is only one participant in existential process which named existent. It indicates things that can be seen by people's eyes. In this case, existential process occurred 13 times or take $28,26 \%$ from all of the data. This process can be found in the text written by student 1 ( 1 clause), student 2 ( 7 clauses), student 3 ( 2 clauses), and student 5 (3 clauses). The clauses which used existential process can be seen in the example below:

\begin{tabular}{|c|c|c|c|c|}
\hline \multirow[t]{2}{*}{ There } & are & \multicolumn{3}{|c|}{ many kinds of fossils, roc } \\
\hline & Existential & & & Existent \\
\hline \multirow[t]{2}{*}{ There } & are & some $\mathrm{g}$ & ames. & \\
\hline & Existential & Exist & tent & \\
\hline \multirow[t]{2}{*}{ There } & is & a park & for & isitor \\
\hline & Existential & Existent & Circul & stances \\
\hline
\end{tabular}

Since the text written is descriptive text about place, students used existential clauses to tell the reader what things that exist around the place students described. From the example above, existential processes are expressed by verb ' $i s$ ' and 'are'. Then, the phrases 'many kinds of fossils, rocks and minerals', 'some games', and 'a park' are existent of something. Unfortunately, only the third clause which has circumstantial element. It is 'for visitor'. The word 'there' in the clause above has no experiential meaning.

The next process which occurred is mental process. It is about $17,39 \%$ ( 8 clauses). This process can be found in the text written by student 1 ( 1 clause), student 3 ( 2 clauses), student 4 (1 clause), student 5 ( 1 clause), and student 6 ( 2 clauses). Mental process reflected the process of thinking, perceiving, and feeling. There are two participants in mental process, which are Senser and Phenomenon. Some findings of mental processes are:

\begin{tabular}{ccc}
\hline I & feel & Comfortable \\
\hline Senser & Mental & Phenomenon \\
\hline
\end{tabular}

\begin{tabular}{ccc}
\hline I & can see & many different types of mamals. \\
\hline Senser & Mental & Phenomenon \\
\hline & & \\
\hline You & can see & a long bridge \\
\hline Senser & Mental & Phenomenon \\
\hline
\end{tabular}

The clauses above are mental processes because there are two mental processes found, they are 'feel' and 'see'. The word 'feel' refers to affective, while 'see' refers to cognition. 
Therefore, the word ' $I$ ' and ' $y o u$ ' refers to the participant of mental process which is called senser. Senser is entities who sense the phenomenon. The phenomenon of clauses above are 'comfortable', 'many different types of animals', and 'a long bridge'. Students used mental process in the descriptive text to express what people feel, think, and perceive about the things students described.

The last process found is material process. Halliday \& Matthiessen (2004: 197) stated that material process is process of doing and happening. It involves two participants in clause, named Actor and Goal. From 46 clauses analyzed, the writer found 4 clauses regarded as material clause. Material clauses found in the text written by student 1 ( 1 clause), student 4 (1 clause), and student 5 (3 clause). Some of material process found are:

\begin{tabular}{|c|c|c|c|c|}
\hline I & go & there & every holiday & \\
\hline Actor & Material & Goal & Circumstance & \\
\hline The visitors & \multicolumn{2}{|c|}{ always } & visit & it \\
\hline Actor & \multicolumn{2}{|c|}{ Circumstances } & Material & Goal \\
\hline This place & is used & \multicolumn{2}{|c|}{ as tourist destination } & by community \\
\hline Goal & Material & \multicolumn{2}{|c|}{ Circumtances } & Actor \\
\hline
\end{tabular}

The word ' $g o$ ' and 'visit' refers to activity done by the subject, while 'is used' refers to activity done toward the subject. The clauses are material processes because they talk about action. The word 'I', 'the visitor', and 'community' are called Actor, since they are entities which do something. Therefore, 'there', 'it', and 'this place' are called Goal since they refers to entities affected by Actor. Students used material clauses in writing descriptive text to inform reader about activities are habits done by Actor.

Meanwhile, two types of processes are not found in the data analyzed. They are behavioral and verbal process. It happens since the text analyzed is descriptive text, in which, according to Gerot \& Wignell (1995: 208), one of significant lexicogrammatical features of descriptive text is using Attributive and Identifying processes. Thus, the absence of behavioral and verbal process in the data is understandable.

\section{CONCLUSION}

Based on result and discussion above, it can be concluded that there were four processes occured in the data, which are relational, existential, mental, and material process. The most dominant process found was relational process. It is in accordance with Gerot and Wignell's statement that type of processes used in descriptive text are attributive and identifying process, in which they are parts of relational process. The dominance of material process in students' descriptive texts implies that students were aware how descriptive text should be written. 


\section{ACKNOWLEDGMENTS}

This article is the result of hard work, support and guidance of several prople. Thus, we would like to express our gratitude to our supervisor, parents, and friends who have given their supports, prayers, guidance, assistance to us in writing this article.

\section{REFERENCES}

Almurashi, W. A. (2016). An Introduction to Halliday's Systemic Functional Linguistics. Journal for the Study of English Linguistics, 4(1), 70. https://doi.org/10.5296/jsel.v4i1.9423

Anggun, S. K. (2016). An Analysis of Descriptive Text in English Textbook Using Transitivity System ( A Case study of Reading Passages). Journal of English and Education, 4(1), 147-158.

Dirgeyasa, I. W. (2016). College Academic Writing: A Genre-Based Perspective. Jakarta: Kencana.

Gerot, L., \& Wignell, P. (1995). Making Sense of Functional Grammar. Australia: Gerd Stabler.

Halliday, M. A. K., \& Matthiessen, C. M. I. M. (2004). An Introduction to Functional Grammar. London: Arnold. https://doi.org/10.4324/9780203783771

Haratyan, F. (2011). Halliday's SFL and Social Meaning. 2nd International Conference on Humanities, Historical and Social Sciences, 17, 260-264. Retrieved from http://www.ipedr.com/vol17/49-CHHSS 2011-H10074.pdf

Nunan, D. (2003). Practical English Language Teaching. Singapore: McGraw-Hill. Retrieved from http://books.google.com/books?id=v1DMAAAACAAJ\&pgis=1

O 'Donnell, M. (2011). Introduction to Systemic Functional Linguistics for Discourse Analysis. Language, Function and Cognition, 2011-2012.

Senjawati, D. (2016). Transitivity Analysis of Tenth Grade Students '. Journal of English and Education, 4(1), 1-22.

Zahoor, M., \& Janjua, F. (2016). Character construction in tributive songs: Transitivity analysis of the song "I am Malala." Trames, 20(2), 201-213. https://doi.org/10.3176/tr.2016.2.05 